\title{
Promotion of self-care for people with leprosy: educational intervention in the light of Orem's theory
}

\author{
Promoção do autocuidado de pessoas com hanseníase: \\ intervenção educativa à luz da teoria de Orem \\ Promoción del autocuidado en personas con lepra: \\ intervención educativa a luz de teoría de Orem
}

\author{
Jeane Lima Cavalcante \\ Karine Nascimento da Silva ${ }^{a}$ \\ Rayanne de Sousa Barbosa ${ }^{a}$ \\ Maria Corina Amaral Viana ${ }^{a}$ \\ Dayanne Rakelly de Oliveira ${ }^{a}$ \\ Edilma Gomes Rocha Cavalcante ${ }^{a}$
}

How to cite this article: Cavalcante JL, Silva KN, Barbosa RS, Viana MCA, Oliveira DR, Cavalcante EGR. Promotion of self-care for people with leprosy: educational intervention in the light of Orem's theory. Rev Gaúcha Enferm. 2021;42:e20200246. doi: https://doi. org/10.1590/1983-1447.2021.20200246 aniversidade Regional do Cariri (URCA), Programa de Pós-graduação em Enfermagem. Crato, Ceará, Brasil.

\section{ABSTRACT}

Objective: To report the experience of promoting self-care for people with leprosy during educational interventions in the light of Orem's theory.

Method: Experience report of an educational intervention. The analysis was carried out in the light of Orem's theory of nursing systems, in the support-education system.

Results: The guidelines for self-care took into account actions to prevent nasal dryness; and promote decreased sensitivity, joint swelling, pain and dryness in the hands and feet.

Final considerations: The educational intervention to promote self-care favored the protagonism of the person with leprosy who started to carry out preventive care with continuity and autonomy.

Keywords: Leprosy. Self care. Nursing theory. Primary Health Care. Nursing.

\section{RESUMO}

Objetivo: Relatar a experiência da promoção do autocuidado de pessoas com hanseníase durante a realização de intervenções educativas à luz da teoria de Orem.

Método: Relato de experiência de uma intervenção educativa. A análise foi realizada à luz da Teoria dos Sistemas de Enfermagem, de Orem, no sistema apoio-educação

Resultados: As orientações para 0 autocuidado levaram em consideração ações para prevenir o ressecamento nasal e promover a diminuição da sensibilidade, edema nas articulações, dor e ressecamento nas mãos e pés.

Considerações finais: a intervenção educativa para promoção do autocuidado favoreceu o protagonismo da pessoa com hanseníase que passou a realizar os cuidados preventivos com continuidade e autonomia.

Palavras-chave: Hanseníase. Autocuidado. Teoria de enfermagem. Atenção Primária à Saúde. Enfermagem.

\section{RESUMEN}

Objetivo: Informar la experiencia de promover el autocuidado de las personas con lepra durante las intervenciones educativas a la luz de la teoría de Orem.

Método: Informe de experiencia de una intervención educativa. El análisis se realizó a la luz de la Teoría de los Sistemas de Enfermería de Orem, en el sistema de educación de apoyo.

Resultados: Las pautas para el autocuidado tomaron en cuenta acciones para prevenir la sequedad nasal; y promueve la disminución de la sensibilidad, hinchazón en las articulaciones, dolor y sequedad en las manos y los pies.

Consideraciones finales: Intervención educativa para promover el autocuidado favoreció el protagonismo de la persona con lepra que comenzó a realizar cuidados preventivos con continuidad y autonomía

Palabras clave: Lepra. Autocuidado. Teoría de enfermería. Atención Primaria de Salud. Enfermería. 


\section{口INTRODUCTION}

Leprosy is a chronic, infectious disease caused by the bacterium Mycobacterium leprae. It has as characteristic to be an obligate intracellular parasite as it has an affinity for skin cells and peripheral nerve cells. The bacillus has a slow development, with an incubation period between two and five years, which can cause physical disability and deformities ${ }^{(1)}$.

In Brazil, about 23.3\% of people with leprosy have some physical disability, which can be classified as grade I, when associated with loss of sensitivity, and grade II, in the presence of malformations. This highlights the importance of health professionals in the care and prevention of disabilities ${ }^{(2)}$.

In this context, self-care for people with leprosy has benefits for improving the quality of life in terms of physical, psychosocial, and socioeconomic needs. Thus, it leads them to seek prevention and prophylaxis measures with actions that reduce the risk of physical incapacity ${ }^{(3)}$.

Thus, self-care becomes essential in these people's lives, making it relevant to bring in this report the Orem's Theory of Nursing Systems, which has its concept focused on selfcare. The use of this theory allows nurses to assist people affected by leprosy and use communication strategies so that they can learn and perform their daily care, being essential to prevent disabilities arising from the disease and improve their self-esteem.

In this way, this work is justified by the importance of carrying out self-care for people with leprosy, at home, based on Orem's theory, which serves as a guide to qualify nursing practice. In this sense, the nurse has the role of preparing people to receive adequate information for self-care, providing them with empowerment to consciously grasp the appropriate information, which will affect their quality of life, in its different biological and cognitive aspects by the feeling of autonomy and general well-being.

Thus, the objecive is to report the experience of promoting self-care for people with leprosy during educational interventions in the light of Orem's theory.

\section{$\square$ METHOD}

This is a descriptive study, of experience report type, developed in the discipline of Theoretical and Conceptual Basis of Nursing Care, in the Academic Masters Course in Nursing, of a Postgraduate Program in Nursing.

The Theory of Nursing Systems (TNS) by Dorothea Elizabeth Orem was adopted as a theoretical framework. The theorist affirms that taking care of oneself brings positive benefits to the individual, thus, in the support-education system, it is determined that the bonds created must be maintained for nursing production. In this system, the person is able to perform or can learn to perform the measures required by externally or internally oriented therapeutic care. Thus, developing all self-care, the nurse's role is to promote the patient as a self-care agent ${ }^{(4)}$.

Among the six conjectures linked to Orem's self-care, we will work with the assumptions that depart from the premises: "human beings need deliberate and continuous health education about themselves and about the environment to develop practical and intellectual skills in order to continue to the maintenance of their essential human functions"; and "Self-care and the promotion of dependent care require availability, acquisition, preparation and use of resources that determine the need and provision of care ${ }^{\prime \prime(4)}$.

Therefore, the theory brings numerous contributions to the person with leprosy, which can be enhanced through the use of educational interventions, providing various information that support autonomy.

This report mentions the educational interventions that were carried out through a "Bundle". This corresponds to a package that includes three to five cares based on scientific evidence that must be performed together in order to improve the health condition, being mostly directly linked to patient safety ${ }^{(5)}$.

The experience report presents the follow-up of 10 people in treatment for leprosy in the Multibacillary (MB) classification with borderline and Virchorwian clinical form followed at the Dermatology Center and/or Family Health Strategies (FHS) in the municipalities of Cariri, in Ceará.

The educational interventions happened from February to August 2019, at the patients' homes and met the following inclusion criteria: people aged 18 years or over; cases of leprosy reported that were in the sixth month of treatment, due to the possibility of following them in these last months, and with a grade of disability from 0 to 1. Exclusion criteria: people who, after three attempts of contact, were not found during the period of data collection.

To determine the grade of physical disability, ir was used the eye, hand and foot sensitivity test using the Semmes-Weinstein monofilament set (monofilaments: $0.05 \mathrm{~g}, 0.2 \mathrm{~g}$, $2 \mathrm{~g}, 4 \mathrm{~g}, 10 \mathrm{~g}$ and $300 \mathrm{~g}$ ) in the points of evaluation of sensitivity in hands and feet and of flossing (unflavored) to the eyes. It is considered disability grade 1 the absence of response to a monofilament equal to or heavier than $2 \mathrm{~g}$ (violet color).

The interventions for self-care took place at the participants' homes, with three face-to-face educational interventions, interspersed with telephone calls, totaling six interventions. These took an average of 1 hour and 30 minutes and were carried out based on information from the Self-Care with the Face, Hands and Feet booklet ${ }^{(6)}$. The guidelines for 
the promotion of self-care occurred according to the main symptoms presented, according to their needs, which are: a) face: nasal dryness; b) hands and feet: decreased sensitivity, joint swelling, pain and dryness.

For the analysis of self-care, Orem's Theory of Nursing Systems was used as a theoretical framework. It was identified what the person was able to perform in relation to the measures required by externally or internally guided therapeutic care. From the perspective of being an agent of self-care in the actions of a) achieving self-care and b) controlling the exercise and development of self-care ${ }^{(4)}$.

The study was approved by the Research Ethics Committee under opinion number 3,157,899 and participation in the research was legitimized by signing the Free and Informed Consent Form (FICF).

\section{RESULTS AND DISCUSSION}

\section{Description of the experience of the guidelines for promoting self-care and preventing disabilities}

The guidelines for promoting self-care aimed at preventing physical disabilities as a result of leprosy were focused on the needs of the people being monitored, taking into account the premises of the TNS, in the support-education system.

As for the premise regarding the need for health education to develop practical and intellectual skills, the guidelines took into account actions to prevent nasal dryness and promote decreased sensitivity, joint swelling, pain and dryness in the hands and feet.

With regard to the premise on the need for availability, acquisition, preparation and use of resources to achieve the promotion of self-care, the guidelines were accompanied by the availability of a kit that contained a basin, towel, liquid soap, moisturizer, nail saw, sandpaper, mirror and leaflet with guidelines. It is noteworthy that these materials are essential resources to achieve the promotion of self-care and prevention of disabilities, and many of these people did not have the financial conditions that would make it possible to purchase them on their own.

Through follow-up, with educational interventions, selfcare practices allowed for better interaction in providing information and encouragement for self-care. In this sense, educational interventions were essential, according to the positive results reported below: improvement in the nasal septum (no dryness); absence of changes in hands and feet (cracks, wounds or fissures); hydrated, well-groomed upper and lower limbs; and non-evolution to the degree of disability (Grade 2).
Educational interventions make it possible to share knowledge and experiences, contributing to the acquisition of knowledge and promoting reflection and change of attitude regarding self-care practices ${ }^{(7)}$. Therefore, educational interventions allowed knowledge about self-care, through the repetition of the guidelines, putting them into practice, which enabled the non-evolution to physical disabilities.

In addition to the biological aspect, during self-care support, people affected by leprosy stated that the educational interventions contributed to their protagonism in the care process and provided physical and mental well-being. The patient-nurse interaction and educational interventions, planned through a daily routine of care and follow-up, allowed for dialogue, exchange of knowledge, trust and bonding. In response, it was verified through the self-care assessment that people affected by leprosy started to take care of themselves.

\section{Promotion for self-care: nasal dryness}

The guidelines regarding the care that must be performed with the nose vary from cleaning actions, the time interval and practices to avoid injuries and wounds. In this action, it is up to the nurse and/or another health professional to provide this information. In general, in daily life, these cares are not reported by leprosy patients despite their need and importance for the prevention of disabilities ${ }^{(8)}$.

When considering the need for guidelines to promote self-care regarding nasal dryness, people with Leprosy were instructed about the procedure for cleaning the nose 3 to 4 times a day. They were also informed about the need to avoid removing crusts and secretions from the nasal mucosa due to the greater risk of causing wounds.

These self-care measures from the perspective of preventing traumatic injuries require the commitment of professionals at different levels of health care with description and distribution of materials that reinforce these care practices and nasal self-care.

\section{Promotion of self-care and disability prevention: decreased sensitivity and dryness of hands and feet}

A cohort study carried out in India, with the objective of determining the incidence of deformities at diagnosis and during follow-up, indicates that new deformities occur even after completion of treatment. Such consequences demonstrate the need for regular and long-term monitoring of these people(9).

In the self-care with the feet and hands, it was guided on the procedures and frequency of hydration, lubrication, 
and daily self-inspection, with attention to small wounds or reddened areas, the need to wear proper shoes and socks and the importance of protecting the hands in activities.

These actions are necessary to prevent disabilities and physical deformities. For its effective realization, there is a demand that nursing should carry out general interventions, common to various groups, and specific interventions, necessary only for this population ${ }^{(10)}$. In this context, access to information together with the availability of materials and resources provides these patients the appropriate means to develop the skills necessary to peform self-care.

\section{Promotion of self-care: joint swelling and pain}

It is noteworthy that during the treatment of leprosy, patients can develop leprosy reactions or reactional states, classified into type 1 and 2, which result in acute inflammation causing edema, heat, redness, pain, loss of function and, consequently, physical disability ${ }^{(11-12)}$. In this sense, people with leprosy were instructed on the use of corticoids, inflammatory drugs and analgesics according to medical prescription.

The information shown in this experience report emphasizes the fundamental role of nursing in actions aimed at people with leprosy through the promotion of self-care and planning of practices for the prevention of disabilities.

\section{GINAL CONSIDERATIONS}

The promotion of self-care for people affected by leprosy, based on the Theory of Nursing Systems, in the support-education system, proved to be essential to prevent or avoid physical disabilities, in addition to highlighting the importance of making available and acquiring resources for access information and materials.

It was observed that this practice favors the patient's protagonism in the care process and provides autonomy, physical and mental well-being. Thus, this report disseminates and enhances the importance of systematic monitoring through a daily nursing care routine, providing a better understanding of this dimension of care.

Although the educational interventions took place at the patients' homes, there were limitations with regard to the interruption of self-care practices by patients because they prioritized other activities and due to lack of time.
Furthermore, it is highlighted the need for original research or other methods that can provide a better understanding about the dimension of supported self-care for leprosy patients.

\section{REFERENCES}

1. Vêloso DS, Melo CB, Sá TLB, Santos JP, Nascimento EF, Costa FAC. Perfil clínico epidemiológico da Hanseníase: uma revisão integrativa. REAS. 2018;10(1):142937. doi: https://doi.org/10.25248/REAS146_2018

2. Carvalho PS, Brito KKG, Santana EMF, Lima SM, Andrade SSCA, Nóbrega MM, et al. Autocuidado em hanseníase: comportamento de usuários atendidos na rede de atenção primária à saúde. Enferm Brasil. 2019;18(3):398-405. doi: https:// doi.org/10.33233/eb.v18i3.2508

3. Silva PMF, Pereira LE, Ribeiro LL, Santos DCM, Nascimento RD, D'Azevedo SSP. Evaluation of the physical limitations, psychosocial aspects and quality of life of people affected by leprosy. Rev Pesqui Fundam Care Online. 2019;11(1):211-5. doi: https://doi.org/10.9789/2175-5361.2019.v11i1.211-215

4. Orem DE, Taylor SG, Renpenning KM. Nursing: concepts of practice. $6^{\text {th }}$ ed. St. Louis (MI): Mosby; 2001.

5. Silva SG, Nascimento ERP, Salles RK. Bundle to prevent ventilator-associated pneumonia: a collective construction. Texto Contexto Enferm. 2012;21(4):837-44. doi: https://doi.org/10.1590/S0104-07072012000400014

6. Ministério da Saúde (BR). Comunicação e Educação em Saúde Secretaria de Vigilância em Saúde. Departamento de Vigilância Epidemiológica. Autocuidado em hanseníase: face, mãos e pés. Brasília, DF: Ministério da Saúde; 2010 [cited 2020 Jan 10]. Available from: http://bvsms.saude.gov.br/bvs/publicacoes/ autocuidado_hanseniase.pdf

7. Freitas BHBM, Blanco e Silva F, Silva KF, Santos HCD, Silva SEG. Perception of adolescents about leprosy. J Nurs UFPE online. 2019 [cited 2020 Jan 10];13(2):2927. Available from: https://periodicos.ufpe.br/revistas/revistaenfermagem/article/ view/237260/31431

8. Lima MCV, Barbosa FR, Santos DCM, Nascimento RD, D'Azevedo SSP. Practices for self-care in Hansen's disease: face, hands and feet. Rev Gaúcha Enferm. 2018;39:e20180045. doi: https://doi.org/10.1590/1983-1447.2018.20180045

9. Rathod SP, Jagati A, Chowdhary P. Disabilities in leprosy: an open, retrospective anallyses of institutional records. An Bras Dermatol. 2020;95(1):52-6. doi: https:// doi.org/10.1016/j.abd.2019.07.001

10. Oliveira MDS, Lima JOR, Garcia TR, Bachion MM. Useful terms for nursing practice in the care of people with leprosy. Rev Bras Enferm. 2019;72(3):779-87. doi: https://doi.org/10.1590/0034-7167-2017-0684

11. QueirozTA, Carvalho FPB, Simpson CA, Fernandes ACL, Figueirêdo DLA, Knackfuss MI. Clinical and epidemiological profile of patients with leprosy-related reactions. Rev Gaúcha Enferm. 2015;36(esp):185-91. doi: https://doi.org/10.1590/19831447.2015.esp.57405

12. Pinheiro MGC, Miranda FAN, Simpson CA, Carvalho FPB, Ataide CAV, Lira ALBC. Understanding "patient discharge in leprosy": a conceptanalysis. Rev Gaúcha Enferm. 2017;38(4):e63290. doi: https://doi.org/10.1590/1983-1447.2017.04.63290 


\section{- Acknowledgments:}

To the people with Leprosy who were accompanied, for their availability, commitment and welcoming during the visits. To the Health Departments, Nurses and Community Health Agents for making the data available and facilitating access to people with Leprosy. To Déborah Albuquerque Alves Moreira, student of the Academic Master's Degree in Nursing, of the Universidade Regional do Cariri for her contributions and suggestions during the final revision of the manuscript. To the Fundação Cearense de Apoio ao Desenvolvimento Científico e Tecnológico, for granting scholarships to the Postgraduate Program in Nursing, at the Universidade Regional do Cariri.

\section{- Authorship contribution:}

Conceptualization: Jeane Lima Cavalcante, Karine Nascimento da Silva, Rayanne de Sousa Barbosa, Maria Corina Amaral Viana, e Edilma Gomes Rocha Cavalcante. Coleta de dados: Jeane Lima Cavalcante. Formal analysis: Jeane Lima Cavalcante, Karine Nascimento da Silva, Rayanne de Sousa Barbosa. Investigation: Jeane Lima Cavalcante, Karine Nascimento da Silva.

Writing-original draft: Jeane Lima Cavalcante, Karine Nascimento da Silva, Rayanne de Sousa Barbosa, Maria Corina Amaral Viana, Dayanne Rakelly de Oliveira, e Edilma Gomes Rocha Cavalcante.

Writing-review \& editing: Jeane Lima Cavalcante, Karine Nascimento da Silva, Rayanne de Sousa Barbosa, Maria Corina Amaral Viana, Dayanne Rakelly de Oliveira, e Edilma Gomes Rocha Cavalcante.

The authors declare that there is no conflict of interest.

\section{- Corresponding author:}

Karine Nascimento da Silva

E-mail: karine.nascimento@urca.br

\section{Associate editor:}

Rosana Maffacciolli 